\title{
FORMULATION AND PHYSICAL CHARACTERISTICS OF DETAM II SOYBEAN (GLYCINE MAX (L.) MERR) TABLET WITH VARIOUS CONCENTRATION OF SILICON DIOXIDE AND MAGNESIUM STEARATE
}

\author{
RIKA YULIA ${ }^{1}$, ADITYA TRIAS PRADANA ${ }^{2 *}$, SYLVIA SILVANUS SIE ${ }^{1}$, FITRIA ATIKA SURI ${ }^{1}$ \\ ${ }^{1}$ Department of Clinical and Community Pharmacy, Faculty of Pharmacy, University of Surabaya, Jl. Raya Kalirungkut, Surabaya, \\ Indonesia. ${ }^{2}$ Department of Pharmaceutics, Faculty of Pharmacy, University of Surabaya, Jl. Raya Kalirungkut, Surabaya, Indonesia. \\ Email: aditya_trias@staff.ubaya.ac.id
}

Received: 21 February 2017, Revised and Accepted: 16 October 2017

\section{ABSTRACT}

Objective: This research was conducted to obtain several formulation and evaluate the physical characteristics of the soybean Glycine max (L.) Merr Detam II variety tablets.

Methods: Detam II varieties of soybean (G. $\max$ (L.) Merr.) were cleaned and grinded into 30 mesh-sized powder. Weighed soybean powder and internal phase of excipients (based on the formula) mixed by a Y-cone mixer until homogeneous, and then continue with dry granulation process. Granules formed, then sieved into 16 mesh size, and then, the characteristics examined. Dried granules then mixed with magnesium stearate and silicon dioxide using a drum mixer and compressed into tablets. Physical characteristics of tablets measured at $0,4,7,14,21$, and 28 days.

Results: Evaluation was done for particle size distribution, moisture content (MC), flow properties, weight uniformity, friability, hardness, and disintegration time. Dry granulation was the best method to improve the characteristics of soybean powder with poor compressibility, poor flowability, and hygroscopic. Flow properties of the granules became better for Formula II and III by adding the concentration of silicon dioxide. The formulas also showed the good uniformity of weight, size, MC, friability, and disintegration time. Reducing the lubricant until 0, 5\% of the formula made differences in friability, hardness, and disintegration time better than another formula.

Conclusion: The result of this research indicates that differences in silicon dioxide and magnesium stearate composition of the formula can affect the physical characteristics of soybean (G. $\max ($ L.) Merr.) tablets.

Keywords: Soybean (G. $\max$ (L.) Merr), Detam II variety, Tablet, Dry granulation, Silicon dioxide, Magnesium stearate.

(c) 2018 The Authors. Published by Innovare Academic Sciences Pvt Ltd. This is an open access article under the CC BY license (http://creativecommons. org/licenses/by/4. 0/) DOI: http://dx.doi.org/10.22159/ajpcr.2018.v11i1.18049

\section{INTRODUCTION}

Free radicals are reactive and oxidize other molecules nearby such as proteins, DNA, lipids, and others. Free radicals can be inhibited by the presence of antioxidants. Antioxidants are substances that protect cells from free radical damage. Antioxidants interact and stabilize free radicals. Antioxidants are molecules that prevent the oxidation of other molecules. The human body has been able to produce an antioxidant commonly called endogenous antioxidant, but endogenous antioxidant alone is not enough and needed antioxidants from outside called exogenous antioxidants $[1,2]$.

There are two sources of exogenous antioxidants, synthetic antioxidants, and natural antioxidants. One of the natural antioxidants is isoflavones or flavonoid derived from plant secondary metabolites [3,4]. Plants are rich in phenolic compounds and flavonoids which have been reported to exert multiple biological effects, such as antioxidant activities, free radical scavengingabilities, anti-inflammatory, and anticarcinogenic [5]. Flavonoids are a class of secondary metabolites which are found mainly in nuts and seeds, and one of them is the soybean plant [6].

Soybean (Glycine max) has became a source of important nutrients since ancient times. Soybeans are easily processed and manufactured into various kinds of food. Soybean (G. max (L.) Merr) Ijen varieties used with Vitamin C as a comparison reported to reduce levels of lead in the blood and liver of male mice [7]. Depend on soybean seeds color, it is divided into two types, yellow and black soybean. Black soybeans have almost same potential of nutrients and result than yellow soybeans and even have a higher functional properties [8].
Flavonoid content of black soybean is 6 times higher than yellow soybeans (total flavonoid content of yellow and black soybean is 0.41 and $2.57 \mathrm{mg}$ equivalent to catechins/gram, respectively), and the antioxidant activity is 15 times higher (DPPH scavenging capacity of yellow and black soybeans is 1.40 and 17.58 mol equivalent per gram, respectively) [9].

Tablet was a dosage form made as a result of black soybean isolfavone optimization. Usually for the natural compound, included soybean has a high amount of moisture content (MC) that affects the flowability become poor, so the formulation will be the key to build the quality of the tablets. Granulation process was done by dry granulation technique to improve the flowability. Granulation is a technique used in the preparation of tablets, in which it involves particles enlargement by agglomeration [10].

Good flow properties needed, and the powder should be easily flows into the die first. [11]. The improvement also developed by changing the composition of glidant and disintegrant of the formula.

\section{MATERIALS AND METHODS}

Materials

The plant material used in this study is the soybean (G. $\max$ (L.) Merr.) Detam II varieties, certified taken from UPBS (Seed Resources Management Unit) Balitkabi (Research Institute for Legumes and Tuber), Malang, East Java in August 2016.

Chemicals used in this study are sodium starch glycolate (SSG) $\left(\right.$ Primojel $^{\circledR}$ ), polyvinylpyrrolidone (PVP) K-30 p.g, lactose anhydrous 
p.g, silicon dioxide (Cab-O-Sil $\left.{ }^{\circledR}\right)$, magnesium stearate p.g, and cellulose powder $\left(\right.$ Vitacel $\left.^{\circledR}\right)$.

\section{Research tools}

The tools used in this study were oven, blender, Retsch vibrator (D-42 759 Haan/Germany), a digital type analytical balance, drum mixer, tapping machine type PT TD200, MC tester, stative, single punch tablet machine (Yung Chuan Industrial Co., Ltd; Taiwan), disintegration time test equipment (disintegration tester, Erweka type of QC-21), Monsanto hardness tester instruments friability tester (rolling and impact durability tester, Erweka type TA 100/TA 200), Oscillating granulator, a standard funnel, stopwatch, pipette drops, and vial.

\section{Methods}

Preparation of (G. max (L.) Merr.) Detam II varieties powder

Soybean (G. $\max ($ L.) Merr.) Detam II varieties were cleaned and then dried directed to the air. Dry soybeans were grinded and homogenized using 30 mesh-sized Sieve into a fine powder. The powder was then stored in an eksikator

\section{Preparation of (G. max (L.) Merr.) Detam II varieties granules}

Soybean and cellulose powder was weighed in the required amount, and then, mixed with a Y-cone mixer until homogeneous. Each anhydrous lactose, PVP K30, Plasdone S 630, and SSG were weighed based on the formula, and then, mixed until homogeneous. The amount of the excipient based on the formula in Table 1. The mixture then compressed into slug and sieved with 16 mesh Oscillating granulator into granules. Physical characteristics of granules were then examined.

\section{Preparation of (G. $\max (L$.$) Merr.) Detam II varieties tablets$}

Dried granules were mixed with magnesium stearate and silicon dioxide using a drum mixer for $3 \mathrm{~min}$. After the flowability was examined, granules then compressed into tablets. Tablet results had $13 \mathrm{~mm}$ diameter and $650 \mathrm{mg}$ tablet weight. Physical characteristics of tablets were measured at time interval of $0,4,7,14,21$, and 28 days.

\section{Granules evaluation}

$M C$

MC value could be expressed by the measurement of dry granules weight and terms good for that $3-5 \%$ MC. The MC was calculated with the following formula:

$$
\mathrm{MC}=\frac{\mathrm{Wa}-\mathrm{Wb}}{\mathrm{Wb}} \times 100 \%
$$

Where Wa means wet granule weight and $\mathrm{Wb}$ is the weight of dry granule.

\section{The particle size distribution}

Siever was prepared from the biggest to the smallest pan in size range by placing the container below the others. The Retsch sieve then placed on the vibrator. After vibrated, then each pan weighed and documented. The target of this examination was obtain good particle distribution of granules and $10-20 \%$ fines.

\section{Compressibility}

Real density value determined by weighed amount of powder, then poured into a measuring glass until readable volume obtained (Vo). Weighed amount of granules putted on volumenometer and tapped, and constant volume obtained recorded as V1. Good compressibility range was $5-25 \%$.

\section{Flowability}

Some granules inserted into the funnel which is closed in the bottom. After the funnel opened, the time required for the granules pass through the funnel and the angle of repose recorded. Maximum flow time of 100 g granule was $10 \mathrm{~s}$, and the angle of repose must be inside the range of $25-40^{\circ}$ based on Table 2 .

\section{Tablet evaluation}

Weight uniformity

Weight uniformity test done by weighing 10 tablets one by one, and the average weight of each tablet calculated. The tablet acceptance value should not be greater than or equal to $15 \%$ based on the Indonesian Pharmacopoeia V [12].

\section{Hardness}

The hardness of the tablet was measured using a Monsanto hardness tester with 20 samples. Each tablet was placed one by one then rotated slowly and precisely until the tablet broke and showed the hardness value on the scale. Hardness requirement generally at least $4 \mathrm{~kg}$.

\section{Friability}

Friability was measured using a friability tester. Samples taken as many as 10 tablets were randomly assigned to tablets with a weight above $650 \mathrm{mg}$. Tablet cleaned one by one and weighed using the analytical balance. The tablet is then inserted into the testing device with a rotation speed of $25 \mathrm{rpm}$ for $4 \mathrm{~min}$. Then, the tablet removed and cleaned from dust. The tablets were weighed and the friability calculated using the following equation:

$$
\% \text { Friability }=\frac{\mathrm{Wa}-\mathrm{Wb}}{\mathrm{Wa}} \times 100 \%
$$

Where $\mathrm{Wa}$ is tablet weight before rotated and $\mathrm{Wb}$ is the final tablet weight.

\section{Disintegration time}

Each tablet was inserted in the basket, and then, the friability tester was started at medium temperature $37 \pm 2^{\circ} \mathrm{C}$. Disintegration time required for testing six tablets should not be $\geq 15 \mathrm{~min}$.

\section{RESULT AND DISCUSSION}

\section{Identification of soybean seed powder (G. $\max$ (L.) Merr) Detam II varieties}

The organoleptic results of soybean (G. $\max$ (L.) Merr) powder Detam II varieties were a yellow with black spots coarse powder, slightly sweet, and have a distinctive odor of soybeans. $1 \mathrm{~kg}$ of crushed soybeans resulted $950 \mathrm{~g}$ soy powder and manufactured into tablets. Organoleptic results of the product shown in Figure 1. MC of the powders was also identified to determine the initial water content in soybean powder, and the amount obtained was $6.11 \%$.

\section{Granules evaluation}

\section{Particle size distribution}

Particle size distribution showed that all of the formulas had the amount of fines below the requirements of $10-20 \%$ [13], but they have a normal size distribution with the major fraction is in the 300-600 ìm shown in Figure 2. particle size. The example of the particle size distribution curve was shown in Fig. 2 for Formula 1 until 3.

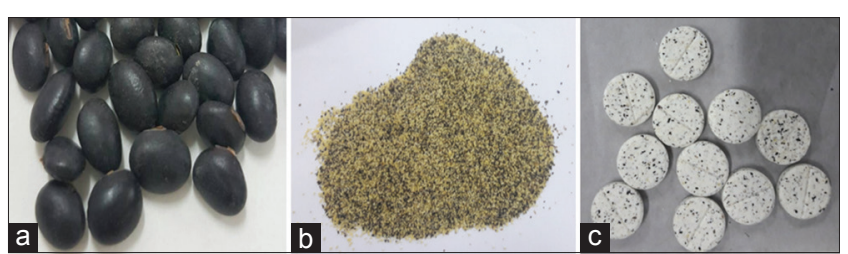

Fig. 1: (a) Soybean (Glycine max L. Merr) Detam II varieties seed,

(b) soybean (G. max L. Merr) Detam II varieties powder, (c) soybean (G. max L. Merr) Detam II varieties tablet 


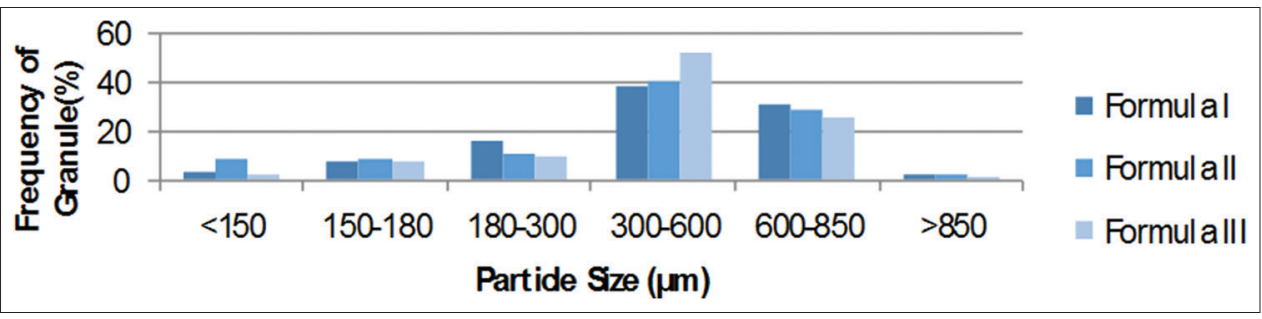

Fig. 2: Particle size distribution curve

Table 1: Formula Detam II varieties soybean tablet

\begin{tabular}{|c|c|c|c|c|c|c|}
\hline \multirow[t]{2}{*}{ Material } & \multirow[t]{2}{*}{ Function } & \multicolumn{5}{|c|}{ Formula } \\
\hline & & I & II & III & VI & VII \\
\hline Detam II black soybean powder & Active substance & $200 \mathrm{mg}$ & $200 \mathrm{mg}$ & $200 \mathrm{mg}$ & $200 \mathrm{mg}$ & $200 \mathrm{mg}$ \\
\hline Magnesium stearate & Lubricants $(\%)$ & 2 & 2 & 2 & 0.5 & 1 \\
\hline \multirow{2}{*}{ Polyvinylpyrrolidone (PVP K30) } & Internal phase binder (\%) & 2 & 2 & 2 & 2 & 2 \\
\hline & External phase binder (\%) & 2 & 2 & 2 & 2 & 2 \\
\hline Silicon dioxide & Glidant (\%) & 0.1 & 0.5 & 1 & 1 & 1 \\
\hline
\end{tabular}

SSG: Sodium starch glycolate

Table 2: Relationship of flow property and angle of reposes

\begin{tabular}{ll}
\hline Flow property & Angle of repose ( ${ }^{\circ}$ ) \\
\hline Excellent & $25-30$ \\
Good & $31-35$ \\
Fair - aid not needed & $36-40$ \\
Passable - may hang up & $41-45$ \\
Poor - must agitate, vibrate & $46-55$ \\
Very poor & $56-65$ \\
Very, very poor & $>66$ \\
\hline
\end{tabular}

Table 3: MC of soybean seeds (G. $\max$ (L.) Merr) Detam II varieties

\begin{tabular}{lcc}
\hline Wb average (g) & Wa average $(\mathrm{g})$ & \% $\mathbf{M C}$ \\
\hline 4.753 & 5.062 & 6.11 \\
\hline MC: Moisture content $G$ max: Glycine $\max$
\end{tabular}

MC: Moisture content, G. max: Glycine $\max$

Table 4: MC of granules

\begin{tabular}{lc}
\hline Formula & \% $\mathbf{M C}$ \\
\hline I & 3.06 \\
II & 2.51 \\
III & 3.21 \\
IV & 2.56 \\
V & 3.13 \\
\hline MC: Moisture content
\end{tabular}

MC

The granules are taken as much as $5 \mathrm{~g}$ (replication 3 times for each formula) and tested moist content. Obtained results for the three formulas meet the requirements, which shown in Table 3 and Table 4. Under the terms, good moist content was between $3 \%$ and $5 \%[14]$.

\section{Compressibility}

All of the formula did not meet the requirement shown in Table 5 [15]. This condition could be due to lack of the amount of fines, so the small particles did not fill cavities between particles. Based on the compressibility value, it can caused the dense of tablet form became less.
Table 5: Compressibility of granules

\begin{tabular}{lll}
\hline Formula & \% Compressibility & $\begin{array}{l}\text { Requirement of } \\
\text { compressibility of 5-25\% }\end{array}$ \\
\hline I & 38.20 & Did not meet the requirement \\
II & 31.46 & Did not meet the requirement \\
III & 36.04 & Did not meet the requirement \\
IV & 33.85 & Did not meet the requirement \\
V & 38.19 & Did not meet the requirement \\
\hline
\end{tabular}

Table 6: Flowability of granules

\begin{tabular}{lll}
\hline Formula & T (s) & Angle of repose $\left(^{\circ}\right.$ ) \\
\hline I & 11.3 & 41.30 \\
II & 8.57 & 38.44 \\
III & 7.50 & 34.56 \\
IV & 9.57 & 34.77 \\
V & 9.50 & 36.24 \\
\hline
\end{tabular}

\section{Flowability}

Flowability of 100 g granules was good shown in Table 6, and most of all formula could flow not more than $10 \mathrm{~s}$. The value of the angle of repose must be between $25^{\circ}$ and $40^{\circ}$ to show good flowability [15]. Formulas I, II, and III determined the improvement of glidant composition in the formula.

Formula III has better flowability than Formulas I and II. It can be caused due to the amount of silicon dioxide as glidant. Glidant amount in formula I as much as $0.1 \%$ is too small to help the poor flowability of Detam II varieties soybean granule in the formula.

\section{Tablet evaluation}

Organoleptic tablet soybean seeds (G. max (L.) Merr) varieties Detam II

The organoleptic test results of the soybean tablet obtained that the tablets are round white with black spots with a slightly sweet taste and a distinctive smell of soybeans.

Tablet weight uniformity

The uniformity test result of 10 unit tablets must be lower than $15 \%$. Tablets from all of the formulas met the requirements 
Table 7: Tablet weight uniformity

\begin{tabular}{llll}
\hline Formula & The average weight \pm SD (g) & Requirements value (\%) & $\begin{array}{l}\text { Uniformity of weight value admission } \\
\text { requirements } \leq \mathbf{1 5 \%} \text { (Depkes RI, 2014) }\end{array}$ \\
\hline I & $0.6504 \pm 0.0133$ & 0.03 & Meet the requirements \\
II & $0.6494 \pm 0.0103$ & 0.02 & Meet the requirements \\
III & $0.6501 \pm 0.0183$ & 0.04 & Meet the requirements \\
IV & $0.6480 \pm 0.0124$ & 0.03 & Meet the requirements \\
V & $0.6434 \pm 0.0081$ & 0.02 & Meet the requirements \\
\hline
\end{tabular}

SD: Standard deviation

Table 8: Tablet hardness

\begin{tabular}{|c|c|c|c|}
\hline Days & Formula & The average of hardness \pm SD (kg) & Requirements of tablet hardness at least $4 \mathrm{~kg}$ (Troy, 2006) \\
\hline \multirow[t]{5}{*}{0} & $\mathrm{I}$ & $1.35 \pm 0.34$ & Did not meet the requirement \\
\hline & II & $1.25 \pm 0.35$ & Did not meet the requirement \\
\hline & III & $1.6 \pm 0.32$ & Did not meet the requirement \\
\hline & IV & $4.12 \pm 0.10$ & Meet the requirement \\
\hline & $\mathrm{V}$ & $2.90 \pm 0.87$ & Did not meet the requirement \\
\hline \multirow[t]{4}{*}{4} & I & $1.35 \pm 0.24$ & Did not meet the requirement \\
\hline & II & $1.05 \pm 0.16$ & Did not meet the requirement \\
\hline & IV & $3.92 \pm 0.09$ & Did not meet the requirement \\
\hline & $\mathrm{V}$ & $2.45 \pm 0.50$ & Did not meet the requirement \\
\hline \multirow[t]{5}{*}{7} & $\mathrm{I}$ & $1.3 \pm 0.35$ & Did not meet the requirement \\
\hline & II & $1.4 \pm 0.35$ & Did not meet the requirement \\
\hline & III & $1 \pm 0.00$ & Did not meet the requirement \\
\hline & IV & $2.15 \pm 0.53$ & Did not meet the requirement \\
\hline & $\mathrm{V}$ & $2.00 \pm 0.47$ & Did not meet the requirement \\
\hline \multirow[t]{4}{*}{14} & $\mathrm{I}$ & $1.25 \pm 0.26$ & Did not meet the requirement \\
\hline & III & $0.675 \pm 0.24$ & Did not meet the requirement \\
\hline & IV & $1.83 \pm 0.21$ & Did not meet the requirement \\
\hline & $\mathrm{V}$ & $1.58 \pm 0.44$ & Did not meet the requirement \\
\hline \multirow[t]{5}{*}{21} & I & $1.45 \pm 0.37$ & Did not meet the requirement \\
\hline & II & $1.4 \pm 0.32$ & Did not meet the requirement \\
\hline & III & $1.3 \pm 0.48$ & Did not meet the requirement \\
\hline & IV & $2.15 \pm 0.24$ & Did not meet the requirement \\
\hline & $\mathrm{V}$ & $1.80 \pm 0.35$ & Did not meet the requirement \\
\hline \multirow[t]{5}{*}{28} & I & $0.75 \pm 0.24$ & Did not meet the requirement \\
\hline & II & $1 \pm 0.00$ & Did not meet the requirement \\
\hline & III & $0.575 \pm 0.12$ & Did not meet the requirement \\
\hline & IV & $1.98 \pm 0.18$ & Did not meet the requirement \\
\hline & $\mathrm{V}$ & $1.35 \pm 0.27$ & Did not meet the requirement \\
\hline
\end{tabular}

SD: Standard deviation

shown in Table 7. Fair flowability helped the granule to enter the compression dies even there was a deviation also from target weight of $0.650 \mathrm{~g}$.

\section{Tablet hardness}

Hardness of tablet was examined for all formulas with several intervals of sampling time and the result shown in Table 8. Hardness of tablet decreased time by time when it placed inside the climatic chamber with controlled condition in $40^{\circ} \mathrm{C}$ temperature and $75 \%$ $\mathrm{RH}$. The formulation could not cover the hygroscopic properties of the active compound determined from decreasing value of tablet hardness.

\section{Tablet friability}

The requirement of maximum friability value was $1 \%$. Friability of Formulas I and II did not meet the requirement on 14, 21, and 28 days, while the Formulas III and V did not meet the requirements since 7 and 4 days, respectively (shown in Table 9). High humidity can lead to break the particle bond, increased porosity, and affected changes in friability. It shown from hardness and friability data that improving the magnesium stearate amount as lubricant also gave the anti-bonding effect between particles. Finally it reduce the hardness and improve the friability of the tabets.

\section{Disintegration time}

Disintegration time of all formulas met the requirement which is $<15$ min. The result in Table 10 showed that higher hydrophobic excipients added in the external phase of the formula affect the disintegration time. The disintegration of tablets needed longer time resulted by improvement of hydrophobic external phase composition. Faster disintegration time could aid the absorption of drugs in the body.

\section{CONCLUSION}

Formulation of Detam II variety soybean tablets with several concentration of silicon dioxide and magnesium stearate was done in this research. Evaluation obtained some data about particle size distribution, MC, flow properties, weight uniformity, friability, hardness, and disintegration time. Soybean powder had poor compressibility, poor flowability, and hygroscopic properties, so dry granulation method was chosen to get tablet dosage form. Flow properties of the granules became better for Formulas II and III by adding the concentration of silicon dioxide as glidant. The formulas also showed a good uniformity of weight, size, MC, friability, and disintegration time. On the other hand, reducing the lubricant composition until $0.5 \%$ of the formula made differences in friability, 
Table 9: Tablet friability

\begin{tabular}{|c|c|c|c|}
\hline Days & Formula & Average friability \pm SD $(\%)$ & Friability requirements should not be $>1 \%$ (USP 37 NF 32,2014 ) \\
\hline \multirow[t]{5}{*}{0} & I & $0.40 \pm 0.22$ & Meet the requirements \\
\hline & II & $0.43 \pm 0.42$ & Meet the requirements \\
\hline & III & $0.54 \pm 0.19$ & Meet the requirements \\
\hline & IV & $0.10 \pm 0.02$ & Meet the requirements \\
\hline & $\mathrm{V}$ & $0.27 \pm 0.02$ & Meet the requirements \\
\hline \multirow[t]{5}{*}{4} & I & $0.25 \pm 0.08$ & Meet the requirements \\
\hline & II & $0.22 \pm 0.12$ & Meet the requirements \\
\hline & III & $0.67 \pm 0.09$ & Meet the requirements \\
\hline & IV & $0.51 \pm 0.03$ & Meet the requirements \\
\hline & $\mathrm{V}$ & $1.93 \pm 0.28$ & Did not meet the requirements \\
\hline \multirow[t]{5}{*}{7} & I & $0.44 \pm 0.11$ & Meet the requirements \\
\hline & II & $0.86 \pm 0.34$ & Meet the requirements \\
\hline & III & $3.24 \pm 0.95$ & Did not meet the requirements \\
\hline & IV & $0.25 \pm 0.08$ & Meet the requirements \\
\hline & $\mathrm{V}$ & $1.47 \pm 0.58$ & Did not meet the requirements \\
\hline \multirow[t]{5}{*}{14} & I & $1.34 \pm 0.25$ & Did not meet the requirements \\
\hline & II & $1.46 \pm 0.44$ & Did not meet the requirements \\
\hline & III & $4.51 \pm 1.90$ & Did not meet the requirements \\
\hline & IV & $0.26 \pm 0.07$ & Meet the requirements \\
\hline & $\mathrm{V}$ & $1.47 \pm 0.06$ & Did not meet the requirements \\
\hline \multirow[t]{5}{*}{21} & I & $4.89 \pm 0.34$ & Did not meet the requirements \\
\hline & II & $3.39 \pm 0.48$ & Did not meet the requirements \\
\hline & III & $5.22 \pm 0.62$ & Did not meet the requirements \\
\hline & IV & $0.15 \pm 0.02$ & Meet the requirements \\
\hline & $\mathrm{V}$ & $2.04 \pm 0.37$ & Did not meet the requirements \\
\hline \multirow[t]{5}{*}{28} & I & $2.85 \pm 0.61$ & Did not meet the requirements \\
\hline & II & $2.89 \pm 0.93$ & Did not meet the requirements \\
\hline & III & $4.29 \pm 0.55$ & Did not meet the requirements \\
\hline & IV & $0.56 \pm 0.26$ & Meet the requirements \\
\hline & $\mathrm{V}$ & $3.18 \pm 0.42$ & Did not meet the requirements \\
\hline
\end{tabular}

Table 10: Disintegration time

\begin{tabular}{|c|c|c|c|}
\hline Days & Formula & Average disintegration time (minutes) & Requirement of disintegration time $<15$ min (USP 37 NF 32, 2014) \\
\hline \multirow[t]{5}{*}{0} & I & 7'28'" & Meet the requirements \\
\hline & II & 5'59" & Meet the requirements \\
\hline & III & 9'07" & Meet the requirements \\
\hline & IV & 5'15" & Meet the requirements \\
\hline & $\mathrm{V}$ & 5'35" & Meet the requirements \\
\hline \multirow[t]{5}{*}{4} & I & 7'52"' & Meet the requirements \\
\hline & II & 5'21" & Meet the requirements \\
\hline & III & 4'48"' & Meet the requirements \\
\hline & IV & $4,55^{\prime \prime}$ & Meet the requirements \\
\hline & $\mathrm{V}$ & 4'03" & Meet the requirements \\
\hline \multirow[t]{5}{*}{7} & I & 5’05" & Meet the requirements \\
\hline & II & 4'31" & Meet the requirements \\
\hline & III & 3'46" & Meet the requirements \\
\hline & IV & $4^{\prime} 50^{\prime \prime}$ & Meet the requirements \\
\hline & $\mathrm{V}$ & 4'58" & Meet the requirements \\
\hline \multirow[t]{5}{*}{14} & I & 6'01" & Meet the requirements \\
\hline & II & 5'09" & Meet the requirements \\
\hline & III & 4'35" & Meet the requirements \\
\hline & IV & 3'58" & Meet the requirements \\
\hline & $\mathrm{V}$ & 4'09" & Meet the requirements \\
\hline \multirow[t]{5}{*}{21} & I & 5'34" & Meet the requirements \\
\hline & II & 4'48" & Meet the requirements \\
\hline & III & 6'51" & Meet the requirements \\
\hline & IV & 5'04" & Meet the requirements \\
\hline & $\mathrm{V}$ & 6'04" & Meet the requirements \\
\hline \multirow{5}{*}{28} & I & 6'23" & Meet the requirements \\
\hline & II & 5'27" & Meet the requirements \\
\hline & III & 7'41" & Meet the requirements \\
\hline & IV & 6'38" & Meet the requirements \\
\hline & $\mathrm{V}$ & 6'05" & Meet the requirements \\
\hline
\end{tabular}

hardness, and disintegration time better than another formula. Too much lubrication affected the antibonding effect that increases the friability and reduces the crushing strength of the tablet. The other important problem of soybean powder that must be solved was the hygroscopic characteristic that reduces the physical characteristics of tablets. Formulation of Detam II varieties soybean tablet must 
be consider about the amount of adsorbent and humidity value of production room.

\section{REFERENCES}

1. Hamid A. Antioxidants: Its medicinal and pharmacological applications. Afr J Pure Appl Chem 2010;4:142-51.

2. Pham-Huy LA, He H, Pham-Huy C. Free radicals, antioxidants in disease and health. Int J Biomed Sci 2008;4:89-90.

3. Yulia R, Christyaningsih J, Irmasari V. The antioxidant substances profile of Glycine max L. merr. var. Detam II ultrasonic extract. Res J Pharm Biol Chem Sci 2015;6:502-8.

4. Astuti S. Isoflavon kedelai dan potensinya sebagai penangkap radikal bebas. J Teknol Ind Hasil Pertanian 2008;13:127-31.

5. Pavithra S, Manibala J, Ramachandran J. Evaluation of in-vitro antioxidant and fibrinolytic activity of flavonoid-rich fraction from the whole plant of wedelia Chinensis. Asian J Pharm Clin Res 2016:9:234-9.

6. Sen S, Chakraborty R, Sridhar C, Reddy YS, De B. Free radicals, antioxidants, diseases and phytomedicines: Current status and future prospect. Int J Pharm Sci Rev Res 2010;3:94.

7. Christyaningsih J, Yulia R. The effects Gycine $\max$ L. Merr on Lipid peroxidation and kidney's histopathology in lead intoxication mice. Res
J Pharm Biol Chem Sci 2015;6:1204-10

8. Jeong JH, Jo YN, Kim JH, Eun JD, Dae-Ok K, Jin HH. Black soybean extract protects against TMT-induced cognitive defects in mice. J Med Food 2014; 17:83.

9. Xu BJ, Chang SK. A comparative study on phenolic profiles and antioxidant of legumes as affected by extraction solvents. J Food Sci 2007;72:159-66

10. Salih OS, Nief RA. Effect of natural and synthetic polymers on the properties of candesartan cilexetil matrix tablet prepared by dry granulation. Asian J Pharm Clin Res 2016;9:161-70.

11. Qiu YH, Chen YS, Zhang GG, Yu L, Mantri RV. Developing Solid Oral Dosage Forms: Pharmaceutical Theory and Practice. London: Elsevier; $2017209,561$.

12. Departemen Kesehatan Republik Indonesia. Direktorat Jenderal Pengawas Obat dan Makanan, Farmakope Indonesia V. Jakarta: Departemen Kesehatan Indonesia; 2014.

13. Troy DB. Remington: The Science and Practice of Pharmacy. $21^{\text {st }} \mathrm{ed}$. Baltimore: Lippincott Williams \& Wilkins; 2006. p. 893, 916-7.

14. Hadisoewigyo L, Fudholi A. Sediaan Solida. Yogyakarta: Pustaka Pelajar; 2013.

15. United States Pharmacopeia (USP). The United State Pharmacopoeial Convention. $37^{\text {th }}$ ed. United States: The United States Pharmacopeia (USP); 2014. 